\title{
Chemotherapy-induced peripheral neuropathies: an integrative review of the literature*
}

\author{
Neuropatia periférica induzida pela quimioterapia: revisão integrativa da literatura \\ Neuropatía periférica inducida por la quimioterapia: revisión integradora de la literatura
}

Talita Cassanta Costa ${ }^{1}$, Miriam Lopes², Anna Cláudia Yokoyama dos Anjos ${ }^{3}$, Marcia Maria Fontão Zago ${ }^{4}$

\footnotetext{
* Extracted from the graduate final project course "Neuropatia periférica induzida pela quimioterapia: revisão integrativa da literatura” Certificate in Nursing Oncology, School of

Nursing of Ribeirao Preto, Universidade de Sao Paulo, 2013

${ }^{1}$ Certified Oncology Nurse, School of Nursing of Ribeirao Preto, Universidade de Sao Paulo, Ribeirao Preto, SP, Brazil.

${ }^{2} \mathrm{PhD}$ student, Nursing Graduate Program, School of Nursing of Ribeirao Preto, Universidade de Sao Paulo, Ribeirao Preto, SP, Brazil.

${ }^{3}$ Adjunct professor, Nursing Course, Faculty of Medicine, Universidade Federal de Uberlandia, Uberlandia, MG, Brazil.

${ }^{4}$ Associate professor, School of Nursing of Ribeirao Preto, Universidade de Sao Paulo, Ribeirao Preto, SP, Brazil.
}

\begin{abstract}
Objective: To identify scientific studies and to deepen the knowledge of peripheral neuropathies induced by chemotherapy antineoplastic, seeking evidence for assistance to cancer patients. Method: Integrative review of the literature conducted in the databases Latin American and Caribbean Health Sciences (LILACS), Scientific Electronic Library Online (SciELO), Medical Literature Analysis (PubMed/MEDLINE), the Cochrane Library and the Spanish Bibliographic Index Health Sciences (IBECS). Results: The sample consisted of 15 studies published between 2005-2014 that met the inclusion criteria. Studies showed aspects related to advanced age, main symptoms of neuropathy and chemotherapy agents as important adverse effect of neuropathy. Conclusion: We identified a small number of studies that addressed the topic, as well as low production of evidence related to interventions with positive results. It is considered important to develop new studies proposed for the prevention and/or treatment, enabling adjustment of the patient's cancer chemotherapy and consequently better service.
\end{abstract}

\section{DESCRIPTORS}

Peripheral Nervous System Diseases; Drug Therapy; Neoplasms; Oncology Nursing; Review. 


\section{INTRODUCTION}

Today, cancer is considered a major public health problem in developed and developing countries, conceptualized as multifactorial pathology and classified as a chronic degenerative disease that affects thousands of people annually ${ }^{(1)}$. According to the National Cancer Institute Jose Alencar Gomes da Silva (INCA) ${ }^{(2)}$ there are an estimated 580,000 new cases of cancer in 2014 valid for 2015, data from the National Day Against Cancer and the Brazilian Ministry of Health. The most prevalent types of cancer in the Brazilian population are: skin cancer not melanoma $(182,000)$, prostate cancer $(69,000)$, breast cancer $(57,000)$, colon and rectum cancers $(33,000)$, lung cancer $(27,000)$ and stomach cancer $(20,000)$. Thus, it can be noted that the types of cancers in studies are those that occur more frequently worldwide ${ }^{(2)}$.

Conventional treatments currently used for cancer include surgery, radiotherapy and chemotherapy. New therapeutic modalities have been developed, such as targeted therapies that seek to reach only cancer cells. Chemotherapy is the administration of chemical substances, alone or in combination with other drugs that work at different stages of the cell cycle in order to treat the disease systemically ${ }^{(3)}$.

Chemotherapy generally affects not only cancer cells but also destroy normal cells, as both these cells (cancer and neoplastic cells) follow the same stages of the normal cell cycle. In the case of neoplastic cells, abnormal cell proliferation occurs facilitating tumor growth. Some chemotherapeutic agents are intended to work specifically on cell cycle division phase, preventing the division and growth of cell number or by blocking the process, although they may also destroy cells that have been divided. Thus, these drugs are more effective the earlier they are administered. It is known today that rapid growing tumors are more sensitive to the action of drugs, which results in cell death due to the large number of cells that are in the dividing process ${ }^{(4)}$.

Researches show that chemotherapy has been a mainstay of systemic cancer treatment, but there are studies that point to the adverse effects of drugs, which bring various adverse effects to patients. Among the most common we may mention: nausea and vomiting, fatigue, alopecia, neurogenic pain, diarrhea, constipation, integumentary system changes and neurotoxicity ${ }^{(5)}$.

Peripheral neuropathy is one way of presenting neurotoxicity; which is the deterioration of the peripheral nervous system (PNS), that is, the degeneration of the nerves that carry information from the central nervous system (CNS) to the rest of the body, besides conducting the sensitivity of the body. Any degeneration of the PNS affects the functions of nerves that are fundamental to the human being; peripheral neuropathy distorts and may terminate the mutual information between the CNS and the extremities of the body ${ }^{(6)}$.

There is wide number of neuropathy categories, each with its special characteristics such as: established symptoms, evolution and prognosis. The symptoms come from the affected nerve, being autonomic, motor or sensory ${ }^{(7)}$.

Peripheral neuropathies are caused by chemotherapeutic agents which have varying degrees of toxicity, depending on the type and binding of used drugs, administration time and cumulative dose ${ }^{(8)}$. It may be restricted to the use of antineoplastic agents, and often essential reduction of the dose being administered, and in some cases, discontinuation of treatment due to neuropathy degree ${ }^{(6)}$.

INCA briefly classifies the degrees of peripheral neuropathy in Grade I: decrease in reflexes and light paresthesia; Grade II: decrease in sensitivity and intermediate paresthesia; Grade III: intense decreased in sensitivity and unbearable paresthesia; and Grade IV: absence of reflexes and sensitivity ${ }^{(3)}$.

As described, peripheral neuropathy manifestations are associated with the nerve injury which can harm the patient momentarily or after a long period. Among the most common symptoms associated with neuropathy are: muscle weakness, painful cramps, twitching, muscle atrophy, bone degeneration, changes in skin, hair, nails and sensory and autonomic changes ${ }^{(7)}$.

It is observed that peripheral neuropathy is a serious and significant neurological adverse effect of chemotherapy ${ }^{(9)}$, so it must be monitored from the first symptoms, considering that it may worsen during continued treatment ${ }^{(7)}$.

Thus, the objective of this study was to review and synthesize the knowledge of chemotherapy-induced peripheral neuropathies (CIPN) used in anticancer treatment, seeking evidence for improving care to cancer patients.

\section{METHODS}

We used the integrative review method, through studies of national and international literature. Integrative review involves analysis of research, providing scientific basis for decision making, improving the results obtained in clinical practice, and prospects for expansion of knowledge in specific topic, and help to fill gaps identified in previous studies. The integrative review allows the use of several types of studies to evidence a field of study ${ }^{(10)}$.

This method has well defined development stages, such as: problem identification/research topic and the rationale for the review, search of the scientific literature with prior establishment of inclusion and exclusion criteria to point and organize primary research on the problem/topic, categorization/organization/data collection, using a standard form to extract information that will be important to analyze the retrieved studies, assessment/analysis of the collected data, presentation and comparison of results/interpretation, presentation of the review/synthesis of knowledge and, finally, conclusion ${ }^{(11-12)}$.

Studies were selected according to the following inclusion criteria: primary studies investigating strategies and interventions related to the prevention, minimization and management/treatment of CIPN and which included the following chemotherapy treatment: Paclitaxel, Cisplatin, Oxaliplatin and Carboplatin, in the format of scientific research, national and international, published in Portuguese, English and Spanish. 
Exclusion criteria were: scientific studies regarding peripheral neuropathy, which were not related to chemotherapy, published in languages other than those established in the inclusion criteria, qualitative studies, literature reviews and case reports.

The search was conducted in May/2013 in the electronic databases Latin American and Caribbean Health Sciences (LILACS), Scientific Electronic Library Online (SciELO), Medical Literature Analysis (PubMed/MEDLINE), Cochrane Library, Bibliographical Index Spanish Health Sciences (IBECS). For publication purposes, the search was extended including latest research results, not delimiting the period. In the search, we crossed the following descriptors from the Health Science Descriptors (DeCs) and $\mathrm{MeSH}$ : doença do sistema nervoso periférico (peripheral nervous system diseases), quimioterapia (drug therapy), neoplasia (neoplasms) and neuropatia periférica (peripheral neuropathy) connected by the Boolean operator AND. The main question established for this review was: What are the available evidence in the literature regarding interventions used for the prevention, reduction or treatment/management of peripheral neuropathy induced by chemotherapy in cancer patients?

Chart 1 - Characteristics of included studies - Ribeirao Preto, 2014.

\begin{tabular}{|c|c|c|c|c|c|c|c|c|}
\hline & DATABASES & TITLE OF STUDY & Journal & AUTHORS & COUNTRY & LANGUAGE & YEAR & INSTITUITION \\
\hline E1 & PUBMED & $\begin{array}{l}\text { A randomized, double-blinded, pla- } \\
\text { cebo-controlled phase II trial of re- } \\
\text { combinant human leukemia inhibito- } \\
\text { ry factor (rhuLIF, emfilermin, AM424) } \\
\text { to prevent chemotherapy-induced } \\
\text { peripheral neuropathy. }\end{array}$ & $\begin{array}{l}\text { Clinical } \\
\text { Cancer } \\
\text { Research }\end{array}$ & $\begin{array}{l}\text { Davis, I. D. } \\
\text { et al.(14) }\end{array}$ & Australia & English & 2005 & $\begin{array}{l}\text { Austin Health } \\
\text { Studley Road }\end{array}$ \\
\hline E2 & SCIELO & $\begin{array}{l}\text { Is advanced age associated with in- } \\
\text { creased and severity of chemotherapy } \\
\text { - induced peripheral neuropathy? }\end{array}$ & $\begin{array}{l}\text { Support Care } \\
\text { Cancer }\end{array}$ & $\begin{array}{l}\text { Argyriou, } \\
\text { A.A. et } \\
\text { al.(15) }\end{array}$ & Greece & English & 2006 & $\begin{array}{l}\text { University of } \\
\text { Patias Medical } \\
\text { School }\end{array}$ \\
\hline E3 & PUBMED & $\begin{array}{l}\text { Residual neurotoxicity in ovarian can- } \\
\text { cer patients in clinical remission after } \\
\text { first-line chemotherapy with carbo- } \\
\text { platin and paclitaxel: the Multicenter } \\
\text { Italian Trial in Ovarian cancer (MITO- } \\
\text { 4) retrospective study. }\end{array}$ & BMC Cancer & $\begin{array}{l}\text { Pignata, S. } \\
\text { et al.(16) }\end{array}$ & Italy & English & 2006 & $\begin{array}{l}\text { National } \\
\text { Cancer } \\
\text { Institute }\end{array}$ \\
\hline E4 & MEDLINE & $\begin{array}{l}\text { Statistical identification of predictors } \\
\text { for peripheral neuropathy associated } \\
\text { with administration of bortezomib, } \\
\text { taxanes, oxaliplatin or vincristini us- } \\
\text { ing ordered logistic regression analy- } \\
\text { sis. }\end{array}$ & $\begin{array}{l}\text { Anticancer } \\
\text { Drugs }\end{array}$ & $\begin{array}{l}\text { Kanbayashi, } \\
\text { Y. et al.(17) }\end{array}$ & Japan & English & 2010 & $\begin{array}{l}\text { University } \\
\text { Hospital Kyoto } \\
\text { Prefectual }\end{array}$ \\
\hline E5 & MEDLINE & $\begin{array}{l}\text { Clinical randomized controlled study } \\
\text { on acupuncture for treatment of pe- } \\
\text { ripheral neuropathy induced by che- } \\
\text { motherapeutic drugs. }\end{array}$ & $\begin{array}{l}\text { Znhongguo } \\
\text { Zhen Jiu. }\end{array}$ & $\begin{array}{l}\text { Xu, W. R. et } \\
\text { al.(18) }\end{array}$ & China & English & 2010 & $\begin{array}{l}\text { Bujing } \\
\text { University of } \\
\text { CM }\end{array}$ \\
\hline E6 & PUBMED & $\begin{array}{l}\text { Precise evaluation of chemotherapy- } \\
\text { induced peripheral neuropathy using } \\
\text { the visual analogue scale: a quantita- } \\
\text { tive and comparative analysis of neu- } \\
\text { ropathy occurring with paclitaxel-car- } \\
\text { boplatin and docetaxel-carboplatin } \\
\text { therapy. }\end{array}$ & $\begin{array}{l}\text { International } \\
\text { Journal } \\
\text { Clinical } \\
\text { Oncology }\end{array}$ & $\begin{array}{l}\text { Takemoto, } \\
\text { S. et al.(19) }\end{array}$ & Japan & English & 2012 & $\begin{array}{l}\text { University } \\
\text { School of } \\
\text { Medicine }\end{array}$ \\
\hline E7 & MEDLINE & $\begin{array}{l}\text { Falls in persons with chemotherapy- } \\
\text { induced peripheral neuropathy. }\end{array}$ & $\begin{array}{l}\text { Support Care } \\
\text { Cancer }\end{array}$ & $\begin{array}{l}\text { Tofthagen, } \\
\text { C; } \\
\text { Overcash, J; } \\
\text { Kip, K.(20) } \\
\end{array}$ & USA & English & 2012 & $\begin{array}{l}\text { College of } \\
\text { Nursing } \\
\text { University of } \\
\text { South Florida }\end{array}$ \\
\hline E8 & MEDLINE & $\begin{array}{l}\text { Taxane-induced peripheral neuropa- } \\
\text { thy and health-related quality of life } \\
\text { in postoperative breast cancer pa- } \\
\text { tients undergoing adjuvant chemo- } \\
\text { therapy: N-SAS BC 02, a randomized } \\
\text { clinical trial. }\end{array}$ & $\begin{array}{l}\text { Support Care } \\
\text { Cancer }\end{array}$ & $\begin{array}{l}\text { Shimozuma, } \\
\text { K. et al.(21) }\end{array}$ & Japan & English & 2012 & - \\
\hline
\end{tabular}

continued...
Searching the databases, 76 studies were preselected; after reading all the titles and then abstracts, 15 primary studies were selected according to the inclusion and exclusion criteria.

Studies found in IBECS database were excluded because they did not fulfil the inclusion criteria; the studies found in LILACS and Cochrane databases were not counted because they were duplicated by PubMed/MEDLINE and, since the search occurred primarily in the latter databases. Data collection was performed using the proposed instrument, developed and validated by Ursi ${ }^{(13)}$.

The final sample consisted of 15 studies related to CIPN that focused on the aspects related to prevention, management/treatment/intervention and minimization of CIPN, described by the authors of the primary studies.

\section{RESULTS}

From the collection of information using the above instrument, characteristics, analysis and integrative synthesis of the studies were conducted. Among the studies found, 14(93\%) were retrieved in PubMed/MEDLINE database.

The characteristics of the included studies used in the integrative review are shown in Chart 1. 


\begin{tabular}{|c|c|c|c|c|c|c|c|c|}
\hline & DATABASES & TITLE OF STUDY & Journal & AUTHORS & COUNTRY & LANGUAGE & YEAR & INSTITUITION \\
\hline E9 & PUBMED & $\begin{array}{l}\text { Factors exacerbating peripheral neu- } \\
\text { ropathy induced by paclitaxel plus } \\
\text { carboplatin in non-small cell lung } \\
\text { cancer. }\end{array}$ & $\begin{array}{l}\text { Oncology } \\
\text { Research }\end{array}$ & $\begin{array}{l}\text { Kawakami, } \\
\text { K. et al.(22) }\end{array}$ & Japan & English & 2012 & $\begin{array}{l}\text { Cancer } \\
\text { Institute } \\
\text { Hospital }\end{array}$ \\
\hline E10 & MEDLINE & $\begin{array}{l}\text { Vitamin E for prevention of oxalipla- } \\
\text { tin-induced peripheral neuropathy: a } \\
\text { pilot randomized clinical trial. }\end{array}$ & $\begin{array}{l}\text { São Paulo } \\
\text { Medical } \\
\text { Journal }\end{array}$ & $\begin{array}{l}\text { Afonseca, S. } \\
\text { O. et al.(23) }\end{array}$ & Brazil & English & 2013 & $\begin{array}{l}\text { Faculdade de } \\
\text { Medicina do } \\
\text { ABC }\end{array}$ \\
\hline E11 & PUBMED & $\begin{array}{l}\text { Goshajinkigan oxaliplatin neurotox- } \\
\text { icity evaluation (GONE): a phase 2, } \\
\text { multicenter, randomized, double- } \\
\text { blind, placebo-controlled trial of } \\
\text { goshajinkigan to prevent oxaliplatin- } \\
\text { induced neuropathy. }\end{array}$ & $\begin{array}{c}\text { Cancer } \\
\text { Chemotherapy } \\
\text { Pharmacology }\end{array}$ & $\begin{array}{l}\text { Kono, T. et } \\
\text { al.(24) }\end{array}$ & Japan & English & 2013 & - \\
\hline E12 & PUBMED & $\begin{array}{l}\text { Phase III randomized, placebo-con- } \\
\text { trolled, double-blind study of intra- } \\
\text { venous calcium and magnesium to } \\
\text { prevent oxaliplatin-induced sensory } \\
\text { neurotoxicity (N08CB/Alliance). }\end{array}$ & $\begin{array}{l}\text { Journal } \\
\text { Geriatric } \\
\text { Oncology }\end{array}$ & $\begin{array}{l}\text { Loprinzi, C. } \\
\text { L. et al.(25) }\end{array}$ & USA & English & 2014 & $\begin{array}{l}\text { University } \\
\text { Rochester }\end{array}$ \\
\hline E13 & PUBMED & $\begin{array}{l}\text { Oral alpha-lipoic acid to prevent } \\
\text { chemotherapy-induced peripheral } \\
\text { neuropathy: a randomized, double- } \\
\text { blind, placebo-controlled trial. }\end{array}$ & $\begin{array}{c}\text { Support Care } \\
\text { Cancer }\end{array}$ & $\begin{array}{l}\text { Guo, Y. et } \\
\text { al.(26) }\end{array}$ & USA & English & 2014 & $\begin{array}{c}\text { University of } \\
\text { Texas }\end{array}$ \\
\hline E14 & PUBMED & $\begin{array}{l}\text { North Central Cancer Treatment } \\
\text { Group/Alliance trial N08CA-the use } \\
\text { of glutathione for prevention of pacli- } \\
\text { taxel/carboplatin-induced peripheral } \\
\text { neuropathy: a phase } 3 \text { randomized, } \\
\text { double-blind, placebo-controlled } \\
\text { study. }\end{array}$ & Cancer & $\begin{array}{l}\text { Leal, A. D. } \\
\text { et al.(27) }\end{array}$ & USA & English & 2014 & $\begin{array}{l}\text { Mayo Clinic } \\
\text { Rochester }\end{array}$ \\
\hline E15 & PUBMED & $\begin{array}{l}\text { A phase III randomized, placebo-con- } \\
\text { trolled study of topical amitriptyline } \\
\text { and ketamine for chemotherapy-in- } \\
\text { duced peripheral neuropathy (CIPN): } \\
\text { a University of Rochester CCOP study } \\
\text { of } 462 \text { cancer survivors. }\end{array}$ & $\begin{array}{l}\text { Support Care } \\
\text { Cancer }\end{array}$ & $\begin{array}{l}\text { Gewandter, } \\
\text { T. S. et } \\
\text { al.(28) }\end{array}$ & USA & English & 2014 & $\begin{array}{l}\text { University of } \\
\text { Rochester }\end{array}$ \\
\hline
\end{tabular}

Source: Integrative review study.

Of the 15 studies that comprised the final sample, 14 were performed by oncologists, and only one was developed by nurses. Publications occurred in several countries, five studies in Japan, four in the USA and six distributed in other countries.

As a result of the initial search, studies were found in the last two decades, however, after pre-selection, only 15 studies fulfilled the inclusion criteria for the final sample; the publication period was from 2005 to 2014 .
Of the 15 studies found, twelve - E2, E4, E5, E6, E7, E10, E11, E12, E13, E14 and E15 were performed in educational institutions and three - E1, E3 and E9 in teaching hospitals; E8 does not report the institution where the research was conducted. Below, Chart 2 shows information on study design, objectives and characteristics of the subjects of the studies included in this review:

Chart 2 - Designs and objectives of the studies, characteristics of the study subjects - Ribeirao Preto, 2014.

\begin{tabular}{|c|c|c|c|c|}
\hline & STUDY DESIGN & OBJECTIVES & $\begin{array}{l}\text { CHARACTERISTICS OF SUBJECTS OF RESEARCH } \\
\text { AND POLICY PROPOSAL }\end{array}$ & OUTCOMES \\
\hline E1 & $\begin{array}{l}\text { Randomized } \\
\text { and exploratory } \\
\text { clinical study. }\end{array}$ & $\begin{array}{l}\text { To determine whether the } \\
\text { recombinant human leu- } \\
\text { kemia inhibitory factor } \\
\text { (rhuLIF) can prevent or } \\
\text { improve CIPN, treated } \\
\text { with Paclitaxel and Car- } \\
\text { boplatin. }\end{array}$ & $\begin{array}{l}117 \text { patients randomly selected according to gender, } \\
\text { being treated with Carboplatin and Paclitaxel. The } \\
\text { rhuLIF inhibitor factor was administered subcutane- } \\
\text { ously for seven days, starting one day prior to chemo- } \\
\text { therapy; } 36 \text { patients received low doses, } 39 \text { patients } \\
\text { high doses and } 42 \text { patients received a placebo. }\end{array}$ & $\begin{array}{l}\text { The results were not significant } \\
\text { for the prevention or improve- } \\
\text { ment of CIPN. }\end{array}$ \\
\hline E2 & $\begin{array}{l}\text { Exploratory } \\
\text { clinical study. }\end{array}$ & $\begin{array}{l}\text { To test the hypothesis that } \\
\text { advanced age is associ- } \\
\text { ated with the incidence } \\
\text { and severity of CIPN. }\end{array}$ & $\begin{array}{l}35 \text { patients of both sexes with lung or breast cancer } \\
\text { treated with Paclitaxel or Cisplatin, divided between } \\
\text { under } 65 \text { and over or equal to } 65 \text { years old. All pa- } \\
\text { tients underwent an evaluation in the third and sixth } \\
\text { cycle for } 3 \text { months after cessation of chemotherapy. }\end{array}$ & $\begin{array}{l}\text { The researchers found no sig- } \\
\text { nificant data stating the increase } \\
\text { CIPN in advanced age. }\end{array}$ \\
\hline E3 & $\begin{array}{l}\text { Cohort study, } \\
\text { retrospective } \\
\text { and exploratory. }\end{array}$ & $\begin{array}{l}\text { To evaluate/verify the } \\
\text { residual neuropathy in } \\
\text { patients with clinical re- } \\
\text { mission in Carboplatin- } \\
\text { Paclitaxel treatment for } \\
\text { advanced ovarian cancer. }\end{array}$ & $\begin{array}{l}120 \text { female patients included in the study, all receiv- } \\
\text { ing Carboplatin (AUC } 5 \text { ) plus Paclitaxel }(175 \mathrm{mg} / \mathrm{m} 2) \\
\text { every } 3 \text { weeks for } 6 \text { cycles, completing treatment be- } \\
\text { tween } 1998 \text { and } 2003 \text {. }\end{array}$ & $\begin{array}{l}\text { The study revealed that the tox- } \\
\text { icity is caused by the cumulative } \\
\text { dose in the patient's body, trig- } \\
\text { gering the process of peripheral } \\
\text { nerve injury. }\end{array}$ \\
\hline
\end{tabular}




\begin{tabular}{|c|c|c|c|c|}
\hline \multicolumn{5}{|c|}{...continuation } \\
\hline & STUDY DESIGN & OBJECTIVES & $\begin{array}{l}\text { CHARACTERISTICS OF SUBJECTS OF RESEARCH } \\
\text { AND POLICY PROPOSAL }\end{array}$ & OUTCOMES \\
\hline E4 & $\begin{array}{l}\text { Retrospective, } \\
\text { exploratory } \\
\text { study. }\end{array}$ & $\begin{array}{l}\text { To statistically identify } \\
\text { predictors for CIPN. }\end{array}$ & $\begin{array}{l}\text { Retrospective analysis of } 190 \text { patients of both sexes } \\
\text { treated with Bortezomib, Taxanes, Oxaliplatin or Vin- } \\
\text { cristine, from April } 2005 \text { to December } 2008 \text {. }\end{array}$ & $\begin{array}{l}\text { The study identified as predictors } \\
\text { for CIPN: paresthesia and dys- } \\
\text { esthesias, numbness, weakness, } \\
\text { tingling, loss of balance and pain. }\end{array}$ \\
\hline E5 & $\begin{array}{l}\text { Exploratory and } \\
\text { comparative } \\
\text { study. }\end{array}$ & $\begin{array}{l}\text { To search for effective } \\
\text { treatment to CIPN using } \\
\text { acupuncture. }\end{array}$ & $\begin{array}{l}64 \text { cases of patients with CIPN treated with Pacli- } \\
\text { taxel or Oxaliplatin. Randomly divided into groups, } \\
32 \text { cases had used acupuncture and other } 32 \text { used } \\
\text { medicines. The neurotoxicity of both groups were } \\
\text { compared before and after treatment. }\end{array}$ & $\begin{array}{l}\text { The study achieved significant re- } \\
\text { sults only for acupuncture. }\end{array}$ \\
\hline E6 & $\begin{array}{l}\text { Exploratory and } \\
\text { comparative } \\
\text { study. }\end{array}$ & $\begin{array}{l}\text { To investigate whether } \\
\text { CIPN can be properly as- } \\
\text { sess the usage of the visu- } \\
\text { al analogue scale (VAS). }\end{array}$ & $\begin{array}{l}93 \text { patients of both sexes who were treated with Pacl- } \\
\text { itaxel-Carboplatin (TC) or Paclitaxel-Docetaxel (DC), } \\
\text { answered a questionnaire about CIPN with VAS, and } \\
\text { these patients were compared (between those who } \\
\text { received TC and those who received DC). }\end{array}$ & $\begin{array}{l}\text { With the use of VAS, it was fa- } \\
\text { cilitated to the researchers to } \\
\text { conclude that patients with TC } \\
\text { use had CIPN more aggressive } \\
\text { compared to those in DC use. }\end{array}$ \\
\hline E7 & $\begin{array}{l}\text { Exploratory and } \\
\text { prospective } \\
\text { study }\end{array}$ & $\begin{array}{l}\text { To evaluate the possible } \\
\text { risk factors for falls in a } \\
\text { group of patients with } \\
\text { CIPN. }\end{array}$ & $\begin{array}{l}\text { Study included } 109 \text { patients of both sexes who re- } \\
\text { ceived Paclitaxel, Docetaxel, Cisplatin and Oxalipla- } \\
\text { tin or who reported at least one symptom of CIPN. } \\
\text { Each patient was asked to complete the assessment } \\
\text { tool of chemotherapy-induced peripheral neuropathy } \\
\text { (CIPNAT) and a socio-demographic questionnaire. }\end{array}$ & $\begin{array}{l}\text { Data were analyzed using de- } \\
\text { scriptive statistics and logistic } \\
\text { regression, analysis could not } \\
\text { confirm the hypothesis from the } \\
\text { study. }\end{array}$ \\
\hline E8 & $\begin{array}{l}\text { Randomized ex- } \\
\text { ploratory study. }\end{array}$ & $\begin{array}{l}\text { To clarify whether adju- } \\
\text { vant monotherapy, based } \\
\text { on Taxanes, is a viable al- } \\
\text { ternative for the treatment } \\
\text { of patients in postopera- } \\
\text { tive breast cancer and its } \\
\text { impact on HRQOL. } \\
\end{array}$ & $\begin{array}{l}\text { 1,060 patients were enrolled, but CIPN and HRQOL } \\
\text { were evaluated in the first } 300 \text { patients; multicenter } \\
\text { phase III study randomized to one of four adjuvant } \\
\text { regimens: cyclophosphamide followed by Paclitaxel, } \\
\text { cyclophosphamide followed by Docetaxel, Paclitaxel } \\
\text { and Docetaxel. }\end{array}$ & $\begin{array}{l}\text { The CIPN reported by patients } \\
\text { were significantly serious in treat- } \\
\text { ment with Taxanes; however, the } \\
\text { HRQOL results confirmed that } \\
\text { treatment with a single agent tax- } \\
\text { ane is tolerable. }\end{array}$ \\
\hline E9 & $\begin{array}{l}\text { Exploratory } \\
\text { study. }\end{array}$ & $\begin{array}{l}\text { To determine when and } \\
\text { how often CIPN occur in } \\
\text { patients using Paclitaxel } \\
\text { + Carboplatin regimen to } \\
\text { treat non-small cell lung } \\
\text { cancer, and the factors } \\
\text { that aggravate this condi- } \\
\text { tion. }\end{array}$ & $\begin{array}{l}\text { The sample included } 50 \text { patients who received Pacli- } \\
\text { taxel and Carboplatin therapy for treatment of non- } \\
\text { small cell lung cancer. Peripheral neuropathy was } \\
\text { evaluated by the pharmacist through specific ques- } \\
\text { tionnaire, based on the Common Terminology Criteria } \\
\text { for Adverse Events version 3.0. }\end{array}$ & $\begin{array}{l}\text { CIPN was evaluated by the phar- } \\
\text { macist, study of specific questions } \\
\text { based on the criteria of Common } \\
\text { Terminology for Adverse Events. } \\
\text { Univariate analysis was used to } \\
\text { compare a group without, Grade } \\
\text { 1, Grade } 2 \text { or PN (not serious) and } \\
\text { a group with grade } 3 \text { PN (serious). }\end{array}$ \\
\hline E10 & $\begin{array}{l}\text { Randomized } \\
\text { study, explorato- } \\
\text { ry and prospec- } \\
\text { tive pilot type. }\end{array}$ & $\begin{array}{l}\text { To evaluate the efficacy } \\
\text { of Vitamin E in the pre- } \\
\text { vention of Oxaliplatin- } \\
\text { induced peripheral neu- } \\
\text { ropathy. }\end{array}$ & $\begin{array}{l}\text { The study included patients with colorectal and gastric } \\
\text { cancer who were scheduled to receive chemotherapy } \\
\text { based on Oxaliplatin. } 34 \text { patients were randomized, } \\
\text { five days before the start of treatment with Oxalipla- } \\
\text { tin, with } 16 \text { patients randomized to placebo and } 18 \\
\text { patients to vitamin E until the end of chemotherapy. }\end{array}$ & $\begin{array}{l}\text { The researchers found no sig- } \\
\text { nificant data stating the increase } \\
\text { CIPN in advanced age. }\end{array}$ \\
\hline E11 & $\begin{array}{l}\text { Randomized, } \\
\text { double-blind, } \\
\text { multicenter } \\
\text { study. }\end{array}$ & $\begin{array}{l}\text { To estimate improvement } \\
\text { in CIPN treated with Gos- } \\
\text { hajinkigan (traditional } \\
\text { Japanese medicine) in } \\
\text { patients on treatments } \\
\text { to Oxaliplatin-based ad- } \\
\text { vanced colorectal cancer }\end{array}$ & $\begin{array}{l}\text { The study included } 89 \text { patients treated based on Ox- } \\
\text { aliplatin, divided into two groups randomly, } 45 \text { pa- } \\
\text { tients receiving oral tablets of placebo and } 44 \text { patients } \\
\text { receiving goshajinkigan to verify the decrease and/or } \\
\text { improvement in the degree of neuropathy. }\end{array}$ & $\begin{array}{l}\text { The researchers observed with an } \\
\text { acceptable safety margin, a sig- } \\
\text { nificant result in the CIPN degree } \\
\text { of delay without harming the ef- } \\
\text { fectiveness of Oxaliplatin. }\end{array}$ \\
\hline E12 & $\begin{array}{l}\text { Randomized, } \\
\text { double-blind } \\
\text { study. }\end{array}$ & $\begin{array}{l}\text { To test the effectiveness } \\
\text { of calcium and magne- } \\
\text { sium in the prevention of } \\
\text { CIPN before and after the } \\
\text { administration of Oxali- } \\
\text { platin. }\end{array}$ & $\begin{array}{l}353 \text { patients with colon cancer were included in } \\
\text { use of Oxaliplatin, being randomly divided into two } \\
\text { groups. In half of the patients were administered in- } \\
\text { travenous calcium and magnesium before and after } \\
\text { Oxaliplatin, in the other half the same process, but } \\
\text { with placebo. }\end{array}$ & $\begin{array}{l}\text { The results were not satisfactory, } \\
\text { then calcium and magnesium do } \\
\text { not prevent CIPN. }\end{array}$ \\
\hline E13 & $\begin{array}{l}\text { Randomized, } \\
\text { double-blind } \\
\text { study. }\end{array}$ & $\begin{array}{l}\text { To evaluate the admin- } \\
\text { istration of alpha lipoic } \\
\text { acid (ALA) to decrease } \\
\text { the symptoms of CIPN } \\
\text { in patients receiving Cis- } \\
\text { platin regimens and Pa- } \\
\text { clitaxel. }\end{array}$ & $\begin{array}{l}\text { Included in the study patients with cancer for } 18 \text { years } \\
\text { or more, randomly selected, divided into two groups, } \\
\text { one receiving 600mg ALA and another group with } \\
\text { oral placebo, both three times a day for } 24 \text { weeks, in } \\
\text { Cisplatin and Placlitaxel. }\end{array}$ & $\begin{array}{l}\text { ALA was ineffective to decrease } \\
\text { the symptoms caused in CIPN in } \\
\text { patients using Cisplatin and Pa- } \\
\text { clitaxel. }\end{array}$ \\
\hline E14 & $\begin{array}{l}\text { Randomized, } \\
\text { double-blind, } \\
\text { exploratory } \\
\text { study. }\end{array}$ & $\begin{array}{l}\text { To determine whether } \\
\text { the Glutathione would } \\
\text { prevent CIPN in patients } \\
\text { undergoing chemothera- } \\
\text { py with Carboplatin and } \\
\text { Paclitaxel. }\end{array}$ & $\begin{array}{l}185 \text { patients received treatment with Carboplatin } \\
\text { and Paclitaxel, } 91 \text { patients received placebo and } 94 \\
\text { glutathione, } 15 \text { minutes, immediately before chemo- } \\
\text { therapy, random split. }\end{array}$ & $\begin{array}{l}\text { No significant differences in both } \\
\text { groups, glutathione did not pre- } \\
\text { vent patients from developing } \\
\text { CIPN. }\end{array}$ \\
\hline E15 & $\begin{array}{l}\text { Randomized, } \\
\text { double-blind, } \\
\text { multicenter } \\
\text { study. }\end{array}$ & $\begin{array}{l}\text { To investigate the effect } \\
\text { of ketamine } 2 \% \text { plus } 4 \% \\
\text { amitriptyline cream to re- } \\
\text { duce CIPN. }\end{array}$ & $\begin{array}{l}\text { There were } 462 \text { patients of both sexes who received } \\
\text { chemotherapy at least for a month, made use of } \\
\text { ketamine } 2 \% \text {, plus } 4 \% \text { amitriptyline cream, and an- } \\
\text { swered a questionnaire to better assess the symptoms } \\
\text { (pain, numbness, tingling) for six weeks. }\end{array}$ & $\begin{array}{l}\text { After six weeks the researchers } \\
\text { did not obtain any reduction in } \\
\text { the CIPN symptoms. }\end{array}$ \\
\hline
\end{tabular}


Regarding the characteristics of the study participants, there was great variation in the number, from 35-300 individuals within groups of patients. These groups were composed of individuals of both sexes in 12 studies, two developed only with female participants related to ovarian and breast cancers and one study was conducted with only male participants. All studies included only participants over 18 years old. Among the included studies, researches used exploratory, randomized, comparative and cohort designs.

The objectives of the 15 studies were clearly stated by the authors and presented in Chart 2. In general, the studies sought to evaluate the outcomes of interventions, verified predictors of CIPN, as well as other factors related to the occurrence, incidence and impact on life of patients.

Table 1 shows the types of cancers in which participants received chemotherapy in the included studies:
Besides the type of cancer, chemotherapy regimens were identified, of which 11 studies included Paclitaxel as treatment regimen chemotherapy. This drug was used alone in E8 study, as Oxaliplatin, which was also used alone in E10, E11 and E12 studies. The studies E1, E3, E6, E9 and E14 used the combination of chemotherapy drugs Carboplatin and Paclitaxel, corresponding to the most frequently used scheme in five studies. The combination of Paclitaxel occurred with Oxaliplatin chemotherapy in E4 and E5 studies, and Paclitaxel + Oxaliplatin + Cisplatin only in E7. Cisplatin + Oxaliplatin in E13 study and finally Paclitaxel + Cisplatin were used in E2.

Considering the peculiarities of topics related to chemotherapy used in the studies, the topics that are highlighted due to similarity and/or proximity to other research are presented below:

Table 1 - Types of cancers in each study of this integrative review - Ribeirao Preto, 2014.

\begin{tabular}{ll}
\hline Type of cancer & Id of each study \\
\hline Ovarian Cancer & E3 \\
Colorectal/gastric cancer & E10, E11, E12 \\
Lung cancer & E2, E9 \\
Breast cancer & E2, E8 \\
Solid tumors & E1 \\
Not specified & E4, E5, E6, E7, E13, E14, E15 \\
\hline
\end{tabular}

Source: Integrative review studies.

Table 2 - Topics studies - Ribeirao Preto, 2014.

\begin{tabular}{|c|c|c|}
\hline & Topic studied & Studies \\
\hline \multirow[t]{4}{*}{1} & Advanced age & E2, E7 \\
\hline & Symptoms related to CIPN: & \\
\hline & Paresthesia and dysesthesia & E3 \\
\hline & Numbness & E3, E6, E15 \\
\hline \multirow[t]{6}{*}{2} & Weakness & E3, E7 \\
\hline & Tingling & E3, E15 \\
\hline & Loss of balance & E7 \\
\hline & Pain & E6, E15 \\
\hline & Chemotherapy drug & \\
\hline & Oxaliplatin & E4, E5, E7, E10, E11, E12 and E13 \\
\hline \multirow[t]{3}{*}{3} & Paclitaxel & E1, E2, E3, E4, E5, E6, E7, E8, E9, E14 \\
\hline & Carboplatin & E1, E3, E6, E9, E14 \\
\hline & Cisplatin & $\mathrm{E} 2, \mathrm{E} 7, \mathrm{E} 13$ \\
\hline 4 & Cumulative dose & $\mathrm{E} 1, \mathrm{E} 3, \mathrm{E} 8, \mathrm{E} 10$ \\
\hline 5 & Number of cycles & $\mathrm{E} 2, \mathrm{E} 3, \mathrm{E} 6, \mathrm{E} 7$ \\
\hline 6 & Need for Interruption of treatment & E8, E10 \\
\hline 7 & Intervention & E1, E5, E10, E11, E12, E13, E14 and E15. \\
\hline
\end{tabular}

Among the factors related to CIPN, the following were identified:

1 Advanced age: Three studies which associated advanced age to CIPN had different focuses. E2 investigated advanced age as a factor that favors the development of CIPN in patients over 65 years, and E7 associated increased risk of falling in patients who developed CIPN in advanced age. Both could not confirm their hypothesis from the study.

2 Symptoms related to CIPN: Four studies analyzed associated symptoms were described with CIPN and the loss in daily lives of patients in treatment. In these analyzes, two or more chemotherapeutic agents for the treatment was used, Paclitaxel was present in all studies

3 Chemotherapy agents: The selection of chemotherapy agents Paclitaxel, Oxaliplatin, Cisplatin and Carboplatin was established as inclusion criteria, due to the high number of studies found that those involved chemotherapy in cancer treatment in which patients developed CIPN. In the case of this review, 15 studies addressed the topic of chemotherapy. As a result of high index of chemotherapeutic neurotoxicity used during treatment, 
symptoms can remain six months to one year depending on the amount of chemotherapeutic agent administered.

4 Cumulative dose: The studies E1, E3, E8 and E10 proposed to investigate the cumulative dose of chemotherapy drugs in the body as aggravation of CIPN. These studies described that toxicity in the long-term is caused by the cumulative dose in the patient's body, triggering the process of peripheral nerve injury described above.

5 Number of cycles: From studies, four chemotherapy cycles could thus be seen that the greater the number of cycles, the higher the degree of peripheral neuropathy. Only one study associated the number of cycles and the chemotherapy used to fall risk; patients who underwent the treatment based on Paclitaxel, for several cycles showed higher risk of falling when compared to patients undergoing treatment with other chemotherapy.

6 Need for interruption of treatment: Regarding the need for discontinuation of treatment, the E8 and E10 studies indicate that it is necessary reduction of $25 \%$ $50 \%$ of the chemotherapy dose, and depending on the severity of symptoms may be a need to stop treatment until the patient is better.

7 Intervention: Among the eight studies that performed interventions, E1 used the Inhibitory Factor recombinant human Leukemia (rhuLIF), aiming to prevent or ameliorate CIPN. The E10 used vitamin E to try to minimize the CIPN; both results were not significant for the prevention of CIPN or even for treatment. The E5 compared the efficacy of acupuncture and Cobamamina (drug that has antiemetic action and works in the CNS and PNS, of neurotrophic and neurogenerative way; medication administered intramuscularly, aiming to minimize CIPN), and achieved significant results only for acupuncture. E11 evaluated treatment with Goshajinkigan (traditional Japanese medicine) and had a significant improvement in the degree of CIPN of patients. The E12 used calcium and magnesium before and after the use of Oxaliplatin, and E13 administered orally $600 \mathrm{mg}$ ALA in patients treated with Cisplatin and Oxaliplatin, both not improved their CIPN. E14 used glutathione 15 minutes before the chemotherapy sessions, E15 proposed ketamine 2\% + 4\% amitriptyline cream to reduce CIPN, both studies have not achieved positive results.

\section{DISCUSSION}

Through the presented results, it is observed that CIPN is the focus of only a few studies, mainly developed by nurses. However, there was a frequent increase in researches when we consider the ones conducted in the last two years of this review. The integrative review is a valuable method mainly for nursing, because professionals do not usually have enough time to search the literature for all scientific knowledge on peripheral neuropathies, and even carry out a critical analysis of the results of published studies. Thus, it is important for health professionals to also dedicate time to literature review studies, allowing the disclosure of important primary research that can help optimize the work routine and improve the care provided to patients undergoing chemotherapy ${ }^{(29)}$.

The occurrence of CIPN is one of the major difficulties faced by patients undergoing chemotherapy with neurotoxic drugs. The high incidence of CIPN associated with the use of Paclitaxel, which remains long after the interruption of treatment, causes many patients to show losses in their daily activities, restricting their social relationships. Recurrence of CIPN and aggravation of symptoms, often a result in increased morbidity and thus a decrease in quality of life, hence the need to decrease therapeutic dose $\mathrm{e}^{(30)}$.

Maintaining functional autonomy of elderly patients is essential, as well as the development of health promotion and prevention actions that will help to prevent the risk factors and the occurrence of complications of the treatment itself and it can hinder or even disable them to daily activities. Often, it is observed that older people are diagnosed with cancer late, making preventive interventions or minimization of the complications of the disease and the adverse effects of chemotherapy difficult ${ }^{(31)}$.

Regarding symptoms related to chemotherapy, we highlight six types: paresthesia and dysesthesia, numbness, weakness, tingling, loss of balance and pain. The most common neurotoxicity in patients treated with Carboplatin and Paclitaxel is distal sensory neuropathy, that is, a mixture of paresthesia and dysesthesia ${ }^{(7)}$. These become more intense during the night, so disturbing the sleep of the patient, resulting in difficulties in carrying out daily activities and consequently impairing the quality of life of these peo$\mathrm{ple}^{(21)}$. Some studies have reported the numbness with different intensity patterns of neuropathic pain. Anyhow, pain sensations and numbness in the feet lead to changes in the types of footwear, removal of carpets at home, difficulties in running, cycling or standing for prolonged periods ${ }^{(32)}$. All these sensations, associated with changes in everyday life, also raise the chances of accidents within their own homes $^{(5)}$.

The motor toxicity regarded as the most common is the weakness associated with distal motor neuropathy. In general, patients complain of a slight weakness in only one area of the body: the side of the body, limb or muscle, feeling unable to perform their daily activities. Consequently, began to consider that are becoming dependent on others ${ }^{(7)}$. This new status could impact in deep emotional and social changes, leading the patient to retrospection.

Authors from E3 describe the effect of some chemotherapy as tingling, which is classified into 4 grades: the higher the tingling sensation, the higher the degree, so in the grade 4, patients report the sensation to be unbearable and therefore interfere with simple activities of everyday. In the study mentioned, an intervention to minimize, treat or prevent tingling was not proposed, since the objective was to evaluate the residual neuropathy in patients treated with Paclitaxel and Carboplatin.

The loss of balance is a severe impairment related to CIPN, which exposes patients to higher chances to fall with fracture possibilities. This restricts their mobility, since before the insecurity to walk and/or drive, the patient will be 
restricted to the home or limited to travel long distances, requiring the help of others ${ }^{(20)}$.

Pain is a symptom constantly described and reported by cancer patients, and may be present in up to $90 \%$ of those in advanced stages of the disease. Since it is a subjective symptom, it is difficult to explain and delineate it, since it involves physical, emotional and psychosocial aspects of the patient. Pain brings clinical comorbidities, which hinder their approach and result in quality of life impairment ${ }^{(33)}$.

Among the chemotherapeutic addressed in the included studies, all showed significant occurrence of peripheral neuropathy after administration for a certain period. Virtually all patients using Oxaliplatin showed some degree of peripheral neurological dysfunction, showing the occurrence of chronic neuropathy in $29 \%-70 \%$ of patients ${ }^{(24)}$, what draws attention due to significant interference in everyday life, including social, economic and political aspects that will be affected by this, the need for future studies exploring the topic.

The occurrence of peripheral neurotoxicity up to six months after the use of Paclitaxel was 62\% in E3 study; symptoms related to antineoplastic agent are: tingling, numbness and pain in the hands and feet, difficulty walking, among others. There was a higher incidence of pain and numbness in accordance with the studies in patients who received Paclitaxel/Carboplatin, and it occurred to the extent that the number of cycles increased ${ }^{(5)}$. Thus, it is necessary special attention by the whole team treating the patient, seeking proper adjustment of dosages, strategies for prevention and reduction of symptoms.

The cumulative dose was well demonstrated in E1, E3, E8 and E10 studies, which demonstrated the severity of the peripheral neuropathies after cumulative doses of drugs. Late toxicity struck from $15 \%$ to $20 \%$ of patients and was related to cumulative dose, usually more severe and leading to discontinuation of treatment $t^{(22)}$.

Depending on the number of cycles, the patient's tolerance and severity of the symptoms presented was indicated by dose reduction in $25 \%$ to $50 \%$ or sometimes interruption of risk of progression of cancer ${ }^{(24)}$. This finding highlights the need for preventive measures or, early identification of the symptoms of CIPN, given its repercussions.

Some patients are afraid to tell what they really feel or believe that these symptoms are inherent to the effects of anticancer drugs. The relief of adverse events is intended to minimize the occurrence, and not adversely affect the results of treatment, improving the quality and extending the life of these patients.

Given this reality, the oncologist nurse needs to be aware of the emergence of cancer treatment complications, developing actions that are effective, motivating the patient to adherence and interventions that can contribute to achieving good results. Assess the patient at each cycle of treatment, inform symptoms resulting from CIPN, recognize the symptoms and identify actions for early treatment will result in the reduction of losses in the activities of daily living $^{(34)}$ and will improve the general living conditions.

The field of study, interventions and research is increasingly vast, however, we observed in the literature few studies that described the strategies used for prevention, reduction or treatment/management of peripheral neuropathy induced by chemotherapy. We identified only two studies with positive results that affect the patient's response to treatment. The need for innovations in research that benefit to obtain more reliable data can collaborate with the best quality of life of cancer patients ${ }^{(7)}$. Thus, there is the importance of studies focusing on interventions to minimize the occurrence and symptoms of CIPN, during and after chemotherapy.

\section{CONCLUSION}

Among the included studies for the integrative review, only eight addressed an intervention to minimize and/or prevent CIPN. However, six did not produce positive results, only two studies showed positive interventions and contributed to a small but significant improvement in CIPN in patients receiving chemotherapy and/or radiotherapy. Importantly, interventions with positive results encourage other researchers on new quests, or even, in the improvement of those interventions that are still incipient. Although this study has sought evidences for improving the quality of care, we emphasize the scarcity of evidence in the literature on interventions focusing on prevention, early diagnosis and treatment of chemotherapy-induced peripheral neuropathy in cancer patients.

We consider essential the development of new researches that aim to develop strategies for prevention, reduction of occurrences and treatment of CIPN. It is hoped that future researches can fill these gaps identifying complications, contributing significantly to improving care of cancer patients.

\section{RESUMO}

Objetivo: Identificar publicações científicas e aprofundar o conhecimento sobre as neuropatias periféricas induzidas por quimioterápicos antineoplásicos, buscando subsídios para assistência ao paciente oncológico. Método: Revisão integrativa da literatura realizada nas bases de dados Literatura Latino-Americana e do Caribe em Ciências da Saúde (LILACS), Scientific Electronic Library Online (SciELO), Medical Literature Analysis (PubMed/MEDLINE), na biblioteca COCHRANE e no Índice Bibliográfico Espanhol de Ciências da Saúde (IBECS). Resultados: A amostra foi constituída por 15 estudos publicados no período de 2005 a 2014 que atenderam os critérios estabelecidos. Os estudos evidenciaram aspectos relacionados à idade avançada dos pacientes, principais sintomas da neuropatia e os quimioterápicos que têm a neuropatia como efeito adverso relevante. Conclusão: Identificamos pequeno número de estudos que abordavam a temática, assim como baixa produção de evidências relacionadas a intervenções com resultados positivos. Considera-se importante o desenvolvimento de novos estudos com propostas de prevenção e/ou tratamento, possibilitando ajustamento do paciente à quimioterapia antineoplásica e consequentemente melhor assistência.

\section{DESCRITORES}

Doenças do Sistema Nervoso Periférico; Quimioterapia; Neoplasias; Enfermagem Oncológica; Revisão. 
RESUMEN

Objetivo: Identificar las publicaciones científicas y profundizar el conocimiento acerca de las neuropatías periféricas inducidas por quimioterápicos antineoplásicos, buscando subsidios para la asistencia al paciente oncológico. Método: Revisión integradora de la literatura realizada en las bases de datos Literatura Latinoamericana y del Caribe en Ciencias de la Salud (LILACS), Scientific Electronic Library Online (SciELO), Medical Literature Analysis (PubMed/MEDLINE), en la biblioteca COCHRANE y el Indice Bibliográfico Español en Ciencias de la Salud (IBECS). Resultados: La muestra estuvo constituida de 15 estudios publicados en el período de 2005 a 2014 que atendieron los criterios establecidos. Los estudios evidenciaron aspectos relacionados con la edad avanzada de los pacientes, principales síntomas de la neuropatía y los quimioterápicos que tienen la neuropatía como efecto adverso relevante. Conclusión: Identificamos pequeño número de estudios que abordaban la temática, así como poca producción de evidencias relacionadas con las intervenciones con resultados positivos. Se considera importante el desarrollo de nuevos estudios con propuestas de prevención y/o tratamiento, facilitando la adecuación del paciente a la quimioterapia antineoplásica y consecuentemente una mejor asistencia.

\section{DESCRIPTORES}

Enfermedades del Sistema Nervioso Periférico; Quimioterapia; Neoplasias; Enfermería Oncológica; Revisión.

\section{REFERENCES}

1. Herr GE, Kolankiewicz ACB, Berlezi EM, Gomes JS, Magnago TSBS, Rosanelli CP, et al. Avaliação de conhecimentos acerca da doença oncológica e práticas de cuidado com a saúde. Rev Bras Cancerol. 2013;59(1):33-41.

2. Brasil. Ministério da Saúde; Instituto Nacional de Câncer José Alencar Gomes da Silva. Incidência de câncer no Brasil: estimativa 2014 [Internet]. Rio de Janeiro: INCA; 2014 [citado 2014 jan. 20]. Disponível em: http://www.inca.gov.br/estimativa/2014/estimativa-24042014.pdf

3. Brasil. Ministério da Saúde; Instituto Nacional de Câncer José Alencar Gomes da Silva. Ações de enfermagem para o controle do câncer: uma proposta de integração ensino-serviço. Rio de Janeiro: INCA; 2008. Bases do tratamento; p. 369-556.

4. Mohallem AGC, Rodrigues AB. Enfermagem oncológica. 2ª ed. São Paulo: Manole; 2007.

5. Bonassa EMA, Santana TR. Enfermagem em terapêutica oncológica. $3^{\mathrm{a}}$ ed. Rio de Janeiro: Atheneu; 2005.

6. Afonseca SO, Silva MAC, Giglio AD. Abordagem da neuropatia periférica induzida por quimioterapia. Rev Bras Med. 2010;67(n.esp):20-5.

7. Martin LGR, Silva MDP. Chemotherapy induced peripheral neuroparhy: a literature review. Einstein. 2011;9(4 Pt 1):538-44.

8. Driessen CM, Kleine-Bolt KM, Vingerhoets AJ, Mols F, Vreugdenhil G. Assesssing the impact of chemotherapy-induced peripheral neurotoxicity on the quality of life of cancer patients. Support Care Cancer. 2012;20(4):877-81.

9. Cavaletti G, Marmiroli P. Chemotherapy-induced peripheral neurotoxicity. Expert Opin Drug Saf. 2004;3(6):535-46.

10. Polit DF, Beck CT. Essentials of nursing research: methods, appraisal and utilization. Philadelphia: Lippincott Williams \& Wilkins; 2006. Using research in evidence-based nursing practice; p. 457-94.

11. Armstrong D, Bortz P. An integrative review of pressure relief in surgical patients. AORN J. 2001;73(3):645-74.

12. Whittemore R. Combining evidence in nursing research: methods and implications. Nurs Res. 2005;54(1):56-62.

13. Ursi ES. Prevenção de lesões de pele no perioperatório: revisão integrativa da literatura [tese doutorado]. Ribeirão Preto: Escola de Enfermagem de Ribeirão Preto, Universidade de São Paulo; 2005.

14. Davis ID, Kiers L, MacGregor L, Quinn M, Arezzo J, Green M, et al. A randomized, double-blinded, placebo-controlled phase II trial of recombinant human leukemia inhibitory factor (rhuLIF, emfilermin, AM424) to prevent chemotherapy-induced peripheral neuropathy. Clin Cancer Res. 2005;11(5):1890-8.

15. Argyriou AA, Polychronopoulos P, Koutras A, Iconomou G, Gourzis P, Assimakopoulos K, et al. Is advanced age associated with increased incidence and severity of chemotherapy-induced peripheral neuropathy? Support Care Cancer. 2006;14(3):223-9.

16. Pignata S, De Placido S, Biamonte R, Scambia G, Di Vagno G, Colucci G, et al. Residual neurotoxicity in ovarian cancer patients in clinical remission after first-line chemotherapy with carboplatin and paclitaxel: the Multicenter Italian Trial in Ovarian cancer (MITO-4) retrospective study. BMC Cancer. 2006;6:5.

17. Kanbayashi Y, Hosokawa T, Okamoto K, Konishi H, Otsuji E, Yoshikawa T, et al. Statistical identification of predictors for peripheral neuropathy associated with administration of bortezomib, taxanes, oxaliplatin or vincristine using ordered logistic regression analysis. Anticancer Drugs. 2010;21(9):877-81.

18. Xu WR, Hua BJ, Hou W, Bao YJ. Clinical randomized controlled study on acupuncture for treatment of peripheral neuropathy induced by chemotherapeutic drugs. Zhongguo Zhen Jiu. 2010;30(6):457-60.

19. Takemoto S, Ushijima K, Honda K, Wada H, Terada A, Imaishi H, et al. Precise evaluation of chemotherapy-induced peripheral neuropathy using the visual analogue scale: a quantitative and comparative analysis of neuropathy occurring with paclitaxel-carboplatin and docetaxelcarboplatin therapy. Int J Clin Oncol. 2012;17(4):367-72.

20. Tofthagen C, Overcash J, Kip K. Falls in persons with chemotherapy-induced peripheral neuropathy. Support Care Cancer. 2012;20(3):583-9.

21. Shimozuma K, Ohashi Y, Takeuchi A, Aranishi T, Morita S, Kuroi K, et al. Taxane-induced peripheral neuropathy and health-related quality of life in postoperative breast cancer patients undergoing adjuvant chemotherapy: N-SAS BC 02, a randomized clinical trial. Support Care Cancer. 2012;20(12):3355-64.

22. Kawakami K, Tunoda T, Takiguchi T, Shibata K, Ohtani T, Kizu J, et al. Factors exacerbating peripheral neuropathy induced by paclitaxel plus carboplatin in non-small cell lung cancer. Oncol Res. 2012;20(4):179-85. 
23. Afonseca SO, Cruz FM, Cubero Dde I, Lera AT, Schindler F, Okawara M, et al. Vitamin E for prevention of oxaliplatin-induced peripheral neuropathy: a pilot randomized clinical trial. São Paulo Med J. 2013;131(1):35-8.

24. Kono T, Hata T, Morita S, Munemoto Y, Matsui T, Kojima H, et al. Goshajinkigan oxaliplatin neurotoxicity evaluation (GONE): a phase 2, multicenter, randomized, doubleblind, placebocontrolled trial of goshajinkigan to prevent oxaliplatininduced neuropathy. Cancer Chemother Pharmacol. 2013;72(6):1283-90.

25. Loprinzi CL, Qin R, Dakhil SR, Fehrenbacher L, Flynn KA, Atherton P, et al. Phase III randomized, placebo-controlled, double-blind study of intravenous calcium and magnesium to prevent oxaliplatin-induced sensory neurotoxicity (N08CB/Alliance). J Clin Oncol 2014;32(10):997-1005.

26. Guo Y, Jones D, Palmer JL, Forman A, Dakhil SR, Velasco MR, et al. Oral alpha-lipoic acid to prevent chemotherapy-induced peripheral neuropathy: a randomized, double-blind, placebo-controlled trial. Supportive Care Cancer. 2014;22(5):1223-31.

27. Leal AD, Qin R, Atherton PJ, Haluska P, Behrens RJ, Tiber CH, et al. North Central Cancer Treatment Group/Alliance trial N08CA - the use of glutathione for prevention of paclitaxel/carboplatin-induced peripheral neuropathy: A phase 3 randomized, double-blind, placebocontrolled study. Cancer. 2014;120(12):1890-7.

28. Gewandter JS, Mohile SG, Heckler CE, Ryan JL, Kirshner JJ, Flynn PJ, et al. A phase III randomized, placebo-controlled study of topical amitriptyline and ketamine for chemotherapy-induced peripheral neuropathy (CIPN): a University of Rochester CCOP study of 462 cancer survivors. Support Care Cancer. 2014;22(7):1807-14.

29. Mendes KDS, Silveira RCCP, Galvão CM. Revisão integrativa: método de pesquisa para a incorporação de evidências na saúde e na enfermagem. Texto Contexto Enferm. 2008;17(4):758-64.

30. Velasco R, Bruna J. Chemotherapy-induced peripheral neuropathy: an unresolved issue. Neurologia. 2010;25(2):116-31.

31. Oliveira LPBA, Menezes RMP. Representações de fragilidade para idosos no contexto da Estratégia Saúde da Família. Texto Contexto Enferm. 2011;20(2):301-9

32. Bakitas MA. Background noise: the experience of chemotherapy-induced peripheral neuropathy. Nurs Res. 2007;56(5):323-31.

33. Pena R, Barbosa LA, Ishikawa NM. Estimulação elétrica transcutânea do nervo (TENS) na dor oncológica: revisão da literatura. Rev Bras Cancerol. 2008;54(2):193-9.

34. Wickham R. Chemotherapy-induced peripheral neuropathy: a review and implications for oncology nursing practice. Clin J Oncol Nurs. 2007;11(3):361-76. 